FESIEE

Fundación Emilio Soldevilla de la Ecostigación y Desarnolio

\section{Management Letters / Cuadernos de Gestión}

journal homepage: http://www.ehu.eus/cuadernosdegestion/revista/es/

ISSN: 1131-6837 / e-ISSN: 1988-2157

\title{
The impact of social media and e-WOM on the success of reward-based crowdfunding campaigns
}

\section{El impacto de los medios sociales y del e-WOM en el éxito de las campañas de crowdfunding basadas en recompensas}

\author{
Susana Bernardino*, J. Freitas Santos ${ }^{\mathrm{a}}$, Sílvie Oliveira ${ }^{\mathrm{b}}$ \\ a Polytechnic Institute of Oporto/ISCAP/ CEOS.PP - Centre for Organisational and Social Studies of P.Porto, Portugal, Rua Jaime Lopes Amorim, S. Mamede de \\ Infesta,4465-004, Portugal. - jfsantos@iscap.ipp.pt - https://orcid.org/0000-0001-8233-5039 \\ ${ }^{b}$ Polytechnic Institute of Oporto/ISCAP, Rua Jaime Lopes Amorim, S. Mamede de Infesta,4465-004, Portugal. - SilvieTavOliveira@hotmail.com - https://orcid.org/0000-0003- \\ 3400-351X
}

* Corresponding author: Polytechnic Institute of Oporto/ISCAP/ CEOS.PP - Centre for Organisational and Social Studies of P.Porto, Rua Jaime Lopes Amorim, S. Mamede de Infesta,4465-004, Portugal.-susanab@iscap.ipp.pt - https://orcid.org/0000-0002-1639-3553

\section{A R T I C L E I N F O}

Received 11 May 2020,

Accepted 2 November 2020

Available online 25 February 2021

DOI: $10.5295 / \mathrm{cdg} .201300 \mathrm{sb}$

JEL CODES: L26; G41.

\section{A B S T R A C T}

Crowdfunding (CF) is a financial tool that has faced an impressive growth over the past few years, and provides an alternative form of fundraising entrepreneurial projects. However, not all CF campaigns are successful in attracting the investors' interest and obtaining the pledging goal. As CF is built over internet platforms, digital marketing strategies have been used to improve awareness and engage people to contribute with small amounts of money for a given CF campaign.

Hence, this paper intends to study the effect of social media and electronic word of mouth (e-WOM) on the CF campaigns' outcomes and whether these digital marketing strategies might influence the small investors' decision to support or not a reward-based CF campaign.

Using a sample of data from the second largest American reward-based CF platform (Indiegogo), we have applied the multiple OLS regression analysis, to assess the causal effect of various sets of variables in the success rate of a CF campaign.

The findings show that social media and e-WOM strategies play a critical role and have a positive significant impact on a CF campaign.

Keywords: Crowdfunding; Reward-Based Crowdfunding; Social Media; Electronic Word of Mouth (e-WOM); IndieGoGo.

\section{R E S U M E N}

El Crowdfunding (CF) es un instrumento financiero que ha experimentado un crecimiento impresionante en los últimos años y ofrece una forma alternativa de captación de fondos para proyectos empresariales. Sin embargo, no todas las campañas de CF logran atraer la atención de los inversores y obtener el objetivo inicial de la campaña. Dado que las campañas de CF se construyen sobre plataformas de Internet, se han utilizado estrategias de comercialización digital para mejorar la concienciación y lograr que las personas contribuyan con pequeñas cantidades de dinero a una determinada campaña de CF.

Por lo tanto, este documento tiene por objeto estudiar el efecto de los medios sociales y del boca a boca electrónico (e-WOM) en los resultados de las campañas de CF y si estas estrategias de comercialización digital podrían influir en la decisión de los pequeños inversores de apoyar o no una campaña de CF basada en la recompensa. Utilizando una muestra de datos de la segunda mayor plataforma americana de CF basada en la recompensa (Indiegogo), hemos aplicado el análisis de regresión de mínimos cuadrados ordinarios múltiples, para evaluar el efecto causal de varios conjuntos de variables en la tasa de éxito de una campaña de CF.

Los resultados muestran que los medios sociales y las estrategias de e-WOM desempeñan un papel fundamental y tienen un impacto significativo positivo en una campaña de CF.

Palabras clave: Crowdfunding; Crowdfunding basado en la recompensa; medios sociales; boca a boca electrónico (e-WOM); IndieGoGo. 


\section{INTRODUCTION}

The definitions of crowdfunding (CF) emphasise the role of the "crowd" as the main contributor for funding a new entrepreneurial venture (Belleflamme et al. 2015; Moritz and Block 2016). For Lehner (2013), the meaning of CF is targeting a large dispersed audience, dubbed as the "crowd", open to provide small sums of money to fund a project or a venture. Mollick (2014) refers to the efforts made by entrepreneurial individuals and groups - cultural, social, and for-profit - to fund their ventures by drawing on a relatively large number of individuals (the crowd) using the internet, without the intervention of traditional financial brokers. Kuppuswamy and Bayus (2018), considered $\mathrm{CF}$ a modern mechanism for financing informal ventures that enables entrepreneurs to directly call for financial assistance of the general public (i.e., the "crowd") to get their innovative ideas off the ground. Other scholars (e.g. Ahlers et al. 2015) used an umbrella term to describe an increasingly widespread form of fundraising via the internet, whereby groups of people (crowd) pool money, usually through (very) small individual contributions to support a specific venture. As stated by different authors (Gajda and Mason 2013; Agrawal et al. 2015; Baumgardner et al. 2017), there is no doubt that the development of internet and the spread of Information and Communication Technologies (ICT) increased the awareness and the participation of the "crowd" in financing entrepreneurial projects.

Regardless of CF business models that might be considered, the role of the crowd is critical (Mollick 2014). For instance, in the donation or patronage model of CF usually used in philanthropy, the donations are given by the crowd without any expected direct reward. In the lending model, the concession of small loans was made available by the "crowd" that has the expectation of being repaid by the founder plus an interest rate. In the reward-based model, the crowd is seen as early customers that buy products previously to be launched in the mass-market (André et al. 2017). In the equity model, the crowd acquire equity stakes if they support a project, and the persons are treated as equity investors.

The success of a CF campaign occurs when the projects to be financed match with what is valued by the crowd (Belleflamme et al. 2014). In other words, to be considered successful, a CF campaign has to be able to collect all the resources requested by the entrepreneur. To attain this objective the promoter needs to persuade the maximum number of people possible to complete the pledging goal.

The existing statistics indicate that in 2019 the success rate of the Kickstarter CF platform is just about $37.4 \%$ (Statista 2020). To increase the probability of success of the projects posted on the CF platforms the promoters develop digital marketing strategies in order to influence potential investors. In this context, the research aims to analyse if social media and eWOW are important drivers of the investors' decision to participate in a CF campaign.

Although social media and e-WOM has been a subject of interest for several researchers in digital marketing, previous research about the influence of social media and e-WOM on the success of a CF campaign has been scarce (Kaur and Gera 2017). Further, Thies, Wessel and Benlian (2014) claimed for additional research on the dynamic interaction of e-WOM and the campaign contribution behavior of backers in $\mathrm{CF}$, and the consequences of these interactions for other CF platforms.

Therefore, the objective of this article is to investigate the influence of social media (Facebook shares) and e-WOM (online comments) on a reward-based CF campaign, and its relative importance when project's characteristics and founder's profile are considered. The intention is to understand if participation in online communities and the consequent generation of social buzz increase the probability of the success rate of a reward-based CF campaign. Moreover, most of the available studies does not take account of other variables related with the project (e.g. whether the project is technology based vs. culture and arts based), nor does it assess its influence on differentiating the behavior of promoters (e.g. experienced vs. non-experienced entrepreneurs). The analysis of the role of social media and e-WOM within a reward-based CF setting will provide practical recommendations for crowdfundees and platform operators, helping them raise the attention of current and prospective crowdfunders.

The paper is organised as follows. First, we provide the concept and business models of CF, explaining in more detail the reward-based model. In the second section, we analyse the role of social media and e-WOM on CF. Additionally, the next section examines the influence of the characteristics of the project and the founders' attributes on the success rate of a CF campaign. Then, we present the methodology and the model used in the investigation. Following this, we examine the data, ascertain relevant factors and discuss the results. The paper closes with the main conclusions, limitations and future research directions.

\section{THE REWARD-BASED MODEL OF CROWDFUNDING}

Reward-based model is the most popular and widely known type of CF (Cho and Kim 2017; Yu et al. 2017). The reward-based model allows fundraisers to attract a group of funders who essentially receive a reward for backing a project. Contributors receive a "reward" in exchange for the money they offered to the project (André et al. 2017). The reward delivered consists of an incentive system to funders and is also a mean by which entrepreneurs show their gratitude to the investors by supporting a given project asking for funds (Joshi 2008; Paschen 2017). For Cruz (2018, p. 374) "reward-based crowdfunding consists of a financing mode where entrepreneurs pitch for monetary contributions to an idea in exchange for special prizes, appreciation tokens or early editions of products". The reward embedded in a CF campaign could range according to the amount of the contributions offered. The reward often contains a beta-version of a product, the final product (e.g. a book or a game), which may be personalised (signed, a thank you note, etc.), a publicly available mention, or a chance to meet the creators of a project (Mollick and Kuppuswamy 2014). Alternately, the funders could be treated as early customers giving them priority and preference in the access of a new product never launched in the market at a lower price, or with some additional attributes. The pre-purchasing 
of products by early customers, such as software, hardware, or consumer products, is a pattern in this kind of projects (Mollick and Kuppuswamy 2014). This scheme reduces the risks for crowdfundees as the potential losses are minimal, while the main question to crowdfunders is whether the product will satisfy his/her tastes.

Reward-based CF proposals cannot be measured in monetary terms as funders receive tangible but non-financial benefits for their contributions (Belleflamme et al. 2015). Gerber et al. (2012) provide some examples of the relevance of rewards for funders and its role in increasing the participation in $\mathrm{CF}$ communities. Also, taste heterogeneity among crowdfunders seems to play a prominent role as a specific creative project may appear to be extremely important for some funders while completely irrelevant to others (Belleflamme et al. 2015). Herein, the design of the rewards strategy is critical for the CF campaign. As argued by André et al. (2017, p. 325), "rewards must be based on multiple logics including the capacity to generate connections and interactions between backers and the entrepreneurs".

Reward-based CF could be a very promising financial mechanism, that allows entrepreneurs to fundraise money for their projects, without incurring in debt or sacrificing equity (Yu et al. 2017). Besides the easy and costless access to finance, reward-based CF also offers other benefits to potential entrepreneurs. From a market research point of view, the amount of funding and backers could be seen as a predictor of future demand for the product. On the other hand, the success of the campaign may serve as a signal for future funding rounds, possibly through more traditional funding channels (e.g., venture capital or bank loans).

Crowdfunding campaigns are designed for a specific amount (the pledging goal) and held during a given period of time (the campaign duration). If within the time horizon defined the campaign was able to collect the resources asked to reach the funding amount (pledging goal) they will succeed; otherwise, they will not be considered successful. Therefore, the ability to attain the funding goal proposed is traditionally the most common measure of success of a CF campaign (Sahaym, Datta and Brooks 2019), although other approaches could either be considered, even though they are not as common in the literature.

Some of the literature has also focused on the motivations that led individuals to support a certain CF campaign. Choy and Schlagwein (2016) proposed four categories of motivational orientation based on the bifurcation into intrinsic and extrinsic components, and individual and social elements. Intrinsic motivation consists of performing an activity for its own sake, by the pleasure and enjoyment of the task. In contrast, extrinsic motivation refers to people doing something for some external goal outside the task itself (Ryan and Deci 2000). Individual motivation is the willingness to exert high levels of effort toward a goal without regard to the social influence of a community, while social motivation is the willingness to exert a task due to the social influence of a community in order to be accepted by that community (Forgas et al. 2005). According to the results of the qualitative study, Choy and Schlagwein (2016, p. 237) found a first type of motivation called intrinsic-individual that "relate to donors" self-enjoyment or personal satisfaction in supporting the campaign', the second motivation is coined social-intrinsic and "relates to donors" self-enjoyment or personal satisfaction in supporting the campaign in the presence of an online crowd/community', the third is the individual-extrinsic motivation that "relate to donors" desire to realise a particular outcome as a result of supporting the campaign', and the fourth is the social-extrinsic motivation that "relate to donors" desire to realise a particular outcome as a result of supporting the campaign in the presence of an online crowd/community'. The same four categories are proposed by Ryu and Kim (2016) that classified the crowdfunders into: angelic backers (similar to traditional charitable donors), reward hunters (analogous to market investors), avid fans (most passionate sponsor group, similar to members of a brand community), tasteful hermit (active in supporting the project as avid fans, but with lower extrinsic and others-oriented motivations). We can also classify the motives of the crowd based on the type of business model of CF that was used to attract contributions. For instance, in reward-based $\mathrm{CF}$, receiving new products/services from entrepreneurs is an important motivation for backers. Also, helping others and being part of a community that support the development of new products might also encourage more backers to invest in crowdfunding projects (Gerber et al. 2012; Gerber and Hui 2013). In a review of literature, Kaartemo (2017) found that people are driven to participate in CF projects by the attempt to collect rewards and financial returns, help other people in need and support a cause, and to form relationships and be part of a community.

The reasons that could deter crowdfunders (investor) from funding are associated with lack of trust in the crowdfundee (entrepreneur), specifically in platforms where the fund-seeker is allowed to keep the money even when the target is not met (Gerber and Hui 2013). Another problem is time, as online fundraising campaigns require performing a set of managerial tasks that could be a very time-consuming venture that represents a "full-time job" (Cruz 2017). Other major concern is related to the need of display publicly detailed information about the project that increases the risk of copying, especially for projects in the business domain that once imitated might reduce or eliminate the competitive advantage (Hommeravá 2020). Another problem is the disadvantageous position that the crowdfunder has about the crowdfundee that could lead to the risk of moral hazard (such as fraud) and deter some people from putting their money into a given project (André et al. 2017). This is called information asymmetry that refers to "investors lacking information about the risks and/or expected returns of their investments" resulting from the fact that "investors are likely to be less informed than entrepreneurs or borrowers about the quality of the project" (European Commission 2015, p. 25).

In a context of information asymmetry and uncertainty, the investors have to collect the maximum of information possible to reduce risk. Besides the information about the founder of the project, it will be helpful to obtain specific information about the project that could help current and prospective investors (backers) make an informed investment decision. 


\section{THE ROLE OF SOCIAL MEDIA AND E-WOM ON CF CAMPAIGNS}

There is a growing number of academic researchers that have started to study the role of digital marketing strategies in CF, although it is still an under-exploited topic in the empirical literature (Laurell et al. 2019). Specifically, the study of social media and e-WOM strategies within the scope of CF are important issues to analyze.

\subsection{Social media}

Social media has become widely used by firms to create awareness for its products and projects (Sahaym et al. 2019). Social media has further been recognised as very helpful for diffusing information, increasing exposure, improving the site traffic and also promoting engagement with its audience (Sahaym et al. 2019).

In CF, social media is often used to enable entrepreneurs and investors to disseminate information about the campaign after its launch, claim for support and resources, and share project updates with the crowd (Hui et al. 2014). Thus, social media helps entrepreneurs to build ties and reinforce tie strength with existing and potential backers. Besides the improved transparency allowed by social media, the creation of trust is key to engage with prospective investors (Sahaym et al. 2019).

Thus, CF campaigns, especially for new projects in the early stages of development, strongly benefit from the creation of a virtual word of mouth marketing strategy as well as buzz, that positively impacts the collection of funds.

Previous studies have confirmed the relevance of social media on CF success in multiple social platforms (e.g. Beier and Wagner 2015; Borst et al. 2017; Lu et al. 2014). At the same time, existing literature recognise that the vast majority of highly-funded CF projects have used social media to spread awareness among potential supporters and have used multiple advertisements and messages across different platforms (Borst et al. 2017).

To increase the likelihood of collecting funds to attain or surpass the pledging goal of a CF campaign, it is necessary to reach a larger number of potential funders, for which the use of online CF communities on social media is critical (Borst et al. 2017). Social media facilitates the creation and maintenance of social networks (Laurell et al. 2019). Also, the use of social media allows entrepreneurs to obtain, via digital communication means, other connections that are technically available but are not yet activated (latent ties) (Borst et al. 2017). Thus, through social media it is possible to attract more distant people that otherwise would not be possible.

The number of contacts in social media (number of "friends") has also been recognised as having a positive impact on CF success (Mollick 2014; Zheng et al. 2014). However, Borst et al. (2017) findings indicate that weak and latent ties are more important for campaign success than strong ties, that are closer to the entrepreneur and composed mainly of family and friends.

Therefore, social media could be key to atract the "crowd" and establish communication with a broader audience, necessary to support the project, especially in the context of digital interactions where $\mathrm{CF}$ is strongly embedded.

Social media could either perform an important role in stimulating the herd behaviour and to increase the number of sup- porters of a given project/campaign. The empirical work carried out by Borst et al. (2017) confirms the presence of herd behaviour, that results from the influence made by peers in social networks. This herding bahevior contributes positively to the campaigns' success, even though that could be somewhat blurred by the contrary influence of the bystander effect. According to this latter effect, a higher network reduces the likelihood of its members acting and giving support to a campaign, since they are more prone to act as "spectators" (Borst et al. 2017).

In a different way, the investigation of Sahaym et al. (2019) found that entrepreneurial orientation is positively related to the CF campaign success, and this relationship is also mediated by the perceived contributions of social media. The investigation found that innovativeness and proactiveness stimulate companies to recognise the benefits derived from the use of social media platforms to the CF campaign (Sahaym et al. 2019).

From a marketing point of view, the backers can be converted into ambassadors by helping to promote the product in social media (e.g. Facebook, Instagram). As CF is mostly based on social media and digital communication, it is very simple to exchange information about a project with people across country borders. Viral marketing strategies can be used by backers to promote projects as sending information to friends, and other people is easier and faster than using traditional offline technologies. Also, due to the financial involvement of backers in the supported projects, there is an additional motivation to apply the most recent digital communication tools to enhance the awareness of the projects among the social media community (Gierczak et al. 2015).

Facebook is one of the most prominent social media platforms that could be used to promote the projects allowing people to share, discuss, and communicate with others. Most of the reward-based platforms have many accounts linked to Facebook which means that it is easy to determine how many Facebook connections each founder has, thus providing control over the extent of a founder's social network. Large numbers of friends on online social networks have long been associated with the success of crowdfunding campaigns (Mollick and Kuppuswamy 2014). Mollick (2014) drawing on a dataset of over 48,526 projects on Kickstarter concludes that the size of a fundraiser's personal network (number of Facebook connections) is associated with the success of crowdfunding efforts. Similarly, Thies, Wessel and Benlian (2014) examine the effects of social networks on the likelihood of success of 6,000 crowdfunded campaigns on Indiegogo to conclude that social buzz (especially Facebook shares) positively influences project backing. Hong, Hu and Burtch (2015) examine panel data from Indiegogo to conclude that social media activities matter in general but have a slightly different impact. In the case of Facebook, the messages shared are more influential for public goods campaigns, while on Twitter the impact is more on private products campaigns. Further, Lu et al. (2014) based on empirical evidence stress that social networking, especially in the early stage of the project, can significantly increase the probability of attracting funds for a project.

Despite the huge benefits that the use of social media can provide, there is also some risks to be considered, such as those related with privacy issues or loss of control over information overspread through conversations. Since social media platforms are active all the time and conversations can occur even without the presence of the responsible for the project, part of those con- 
trol is transferred to the community as a whole (Sahaym et al. 2019; Summers et al. 2016).

A synthesis of the main impacts of social media in CF campaigns is presented in Table 1.

Table 1

Social media and the impact on reward-based CF campaigns

\begin{tabular}{clc}
\hline \multicolumn{1}{c}{ Factors } & \multicolumn{1}{c}{ Authors } & \multicolumn{1}{c}{ Impact } \\
\hline Social Media & Beier and Wagner (2015) & - Use of social media \\
& Borst et al. (2017) & increases the \\
Lu et al. (2014) & likelihood to attract \\
Mollick (2014) & funds \\
& Mollick and & - Social media extends \\
& Kuppuswamy (2014) & the social network \\
Thies et al. (2014) & of the entrepreneur \\
Zheng et al. (2014) & and the reach of the \\
& & campaign \\
& & Social media \\
& facilitates the \\
& communication with \\
& a broader and more \\
& diverse audience \\
& & Social media can \\
& spread the herd effect \\
&
\end{tabular}

Source: Authors' own elaboration.

The assessment of the relevance of social media for the success of a reward-based CF campaign lead to our first hypothesis:

H1) The presence of a project in social media has a positive impact on the success of a reward-based CF campaign.

\subsection{Eletronic word of mouth (e-WOM)}

Electronic word-of-mouth represents statements made about a product or service made available through social networks to a multitude of people and institutions via the Internet (Kietzmann and Canhoto 2013). Hennig-Thurau et al. (2004 p. 39) define eWOM communication as "any positive or negative statement made by potential, actual, or former customers about a product or company, which is made available to a multitude of people and institutions via the internet'.

Several studies performed in different industries conclude that on-line reccomendations or reviews made by consumers have a positive impact on other consumer purchasing behaviour (e.g. Senecal and Nantel 2004; Chevalier and Mayzlin 2006; Xia and Bechwati, 2008; Xiaofen and Yiling 2009). Analysing specifically the WOM referrals, Trusov et al. (2009) detected a twofold positive impact: in the short term, a very strong direct effect on new customer acquisition; and, a larger and enduring effect of WOM in the mind of the consumer.

The increasing relevance of eWOM is part of a general process of social transformation, where customers are becoming active participants in the business processes. Wherein, they share their ideas and experiences in different platforms (e.g. social networks, blogs, review sites, among others), rather than just having a passive attitude (Summers et al. 2016). Leveraging online word of mouth is important either to spread brand-related information and also to get some feedback from potential supporters and consumers.
Also, e-WOM enables consumers (or other relevant stakeholders) to improve communication and increase the brand popularity of a company or project (Hennig-Thurau et al. 2004). For instance, the comments about the project included in the CF platform allow backers to interact with the founder of the project and other prospective investors generating e-WOM via the Internet.

Empirical evidence shows that lack of information directly related with the quality of the project may lead prospective backers to rely on e-WOM generated by the friends of the fundraiser to clarify some aspects of the project (Belleflamme et al. 2015). The e-WOM has been found to be influential in driving opinions in CF context. Kaminski, Hopp and Lukas (2018) provide empirical evidence that a higher quality campaign in Kickstarter benefits from user-generated e-WOM (online comments) and mass personal e-WOM (Facebook shares) although the social media activity follows the success of the campaign but does not affect the probability of success. Therefore, they recommend that CF campaigns approach their social media activities with caution to attain their campaign goal (Kaminski et al. 2018). Kaur and Gera (2017) confirm the results of previous research stressing that social interaction and connectivity have a positive impact on attracting funds for a CF project. Aggarwal et al. (2012), based on the volume of conversation generated through social media, also find that eWOM has a positive impact on venturing's financing.

Differently, the investigation performed by Summers et al. (2016) indicates that social media buzz has no direct effects on funding, although significant moderating effects were found on the relationship between project signals and funding outcomes. The research also reveals that the influence of social media in CF is a very complex process. Herein, nor all social media buzz has exactly the same contribution, since some buzz is just "noise" and others are "buzzworthy" and influence fundraising. According to Summers et al. (2016), the differential effect of "buzz", depends mainly on the social platform used and the kind of signal embedded, where the broadly diffused and hybrid varieties of buzz leverage the commitments signals. The authors identify a positive impact of "tweets" and Google+ "shares", that is not significantly reached through Facebook "shares".

A summary of the main impacts of e-WOM in CF campaigns could be seen in Table 2 .

Table 2

E-WOM and the impact on reward-based CF campaigns

\begin{tabular}{|c|c|c|}
\hline Factors & Authors & Impact \\
\hline e-WOM & $\begin{array}{l}\text { Hennig-Thurau et al. (2004) } \\
\text { Belleflame et al. (2015) } \\
\text { Kaminski et al. (2018) } \\
\text { Summers et al. (2016) }\end{array}$ & $\begin{array}{l}\text { - The e-WOM effect } \\
\text { improves project } \\
\text { popularity and } \\
\text { recognition } \\
\text { - The e-WOM expands the } \\
\text { "wisdom of the crowd" } \\
\text { - The e-WOM positively } \\
\text { influences the attainment } \\
\text { of funding goals } \\
\text { - The e-WOM } \\
\text { positively influences } \\
\text { the commitment } \\
\text { signalisation }\end{array}$ \\
\hline
\end{tabular}

Source: Authors' own elaboration. 
The assessment of the importance of e-WOM for the success of a reward-based CF campaign lead to our second hypothesis:

H2) The extent of eWOM generated to a project has a positive impact on the success of a reward-based CF campaign.

\section{VARIABLES RELATED TO PROJECT'S CHARACTERISTICS AND FOUNDER'S PROFILE}

The content of a CF campaign includes the pitch, the funding goal, the time frame, the reward-tiers and the communication (Young 2013). The pitch is the first contact point to the audience and contains the project introduction to the project that could be displayed in written and/or video format. The funding goal is the total amount of money that is needed to make the project work. The time frame begins when the campaign is launched and ends when it finishes independently of the required funding goal is attained or not. The reward-tiers are defined according to the strategy of the founder with multiple options in varying price ranges attracting more people. Several researchers (e.g. Koch and Siering 2015; Kraus et al. 2016; Giudici et al. 2017) identified the main influential factors that determine the success of a CF campaign. They could be grouped in two components: the project related factors include the length of the video pitch, the depth of the project's description, project's updates availability, the typology of the project, and the pledging goal target. The promoter related factors encompass the way promoters present themselves on the website of the project, the number of backers, the team and the previous experience of projects on the CF platform.

\subsection{Variables related to project's charateristics}

These variables refer to the project's characteristics that includes the existence and length of the video pitch, the detailed description of the project, the number of updates to the project that are posted on the platform, the technological nature of the project, and the amount of the pledging goal. The empirical evidence provided by Table 3 shows that these variables significantly influence the investment choices of the prospective investors.

Therefore, we hypothesise:

H3) The variables related to the characteristics of the project have a positive impact on the success rate of a CF campaign.

Table 3

Project's related variables and the impact on reward-based CF campaigns

\begin{tabular}{|c|c|c|}
\hline Factors & Authors & Impact \\
\hline Length of the video pitch & $\begin{array}{l}\text { Park and Hopkins (1993) } \\
\text { Jiang and Benbasat (2007) } \\
\text { Young (2013) } \\
\text { Mollick (2014) } \\
\text { Colombo et al. (2015) } \\
\text { Kraus et al. (2016) } \\
\text { Hobbs et al. (2016) } \\
\text { Kaartemo (2017) } \\
\text { Bi et al. (2017) } \\
\text { Courtney et al. (2017) } \\
\text { Zhou et al. (2018) } \\
\text { Koch and Siering (2015; 2019) }\end{array}$ & $\begin{array}{l}\text { - Visual display of information is more effective if it is dynamic } \\
\text { rather than static; } \\
\text { - Visitors perceived websites with video content as more useful than } \\
\text { static-picture formats only; } \\
\text { - Absence of a video was negatively associated with CF success; } \\
\text { - Videos are } 100 \% \text { more successful than the ones that don't have a video; } \\
\text { - Videos, pictures, and other digital marketing activities are relevant in a } \\
\text { CF campaign; } \\
\text { - Videos may increase project acceptance. }\end{array}$ \\
\hline Depth of the project description & $\begin{array}{l}\text { Koch and Siering }(2015 ; 2019) \\
\text { Hobbs et al. }(2016) \\
\text { Kaartemo }(2017) \\
\text { Hossain and Oparaocha }(2017)\end{array}$ & $\begin{array}{l}\text { - Level of the description of the project has a positive effect on a CF } \\
\text { campaign. }\end{array}$ \\
\hline Availability of project updates & $\begin{array}{l}\text { Xu et al. (2014) } \\
\text { Mollick (2014) } \\
\text { Block et al. (2018) } \\
\text { Kuppuswamy and Bayus (2018) } \\
\text { Shahab et al. (2019) }\end{array}$ & $\begin{array}{l}\text { - Updating information about a project with pertinent posts has a } \\
\text { significant positive contribution to the success of a CF campaign; } \\
\text { - Number of updates is a key motivating factor in investment decision; } \\
\text { - Updating frequently the information about the projects can almost } \\
\text { double the probability of funding. }\end{array}$ \\
\hline Typology of the project & $\begin{array}{l}\text { Mollick (2014) } \\
\text { Hörisch (2015) } \\
\text { Chan et al. (2018) } \\
\text { Zhang and Chen (2019) }\end{array}$ & $\begin{array}{l}\text { - Majority of technology projects that failed to reach their funding goals; } \\
\text { - Different product categories show systematic variations in the } \\
\text { attraction of funds. }\end{array}$ \\
\hline Amount of pledging goal & $\begin{array}{l}\text { Mollick (2014) } \\
\text { Frydrych et al. (2014) } \\
\text { Colombo et al. (2015) } \\
\text { Kaartemo (2017) } \\
\text { Gangi and Daniele (2017) } \\
\text { Zhou et al. (2018) } \\
\text { Janku and Kucerova (2018) } \\
\text { Koch and Siering (2015; 2019). }\end{array}$ & - Lower pledging goals are more likely to be successful \\
\hline
\end{tabular}

Source: Authors' own elaboration. 


\subsection{Variables related to founders's profile}

The profile of the promoter of the project can play an important role in influencing prospective investors. Evidence in previous studies (Table 4) shows that the way founder presents himself, the number of backers that attracts to the project, the nature of the team, and the previous experience of the founder act as driving forces to attract investments.

Therefore, we hypothesise:

H4) The variables related to the founder's profile have a positive impact on the success rate of a CF campaign.

Table 4

Founder's related variables and the impact on reward-based CF campaign

\begin{tabular}{|c|c|c|}
\hline Factors & Authors & Impact \\
\hline Founder's presentation & $\begin{array}{l}\text { Egger (2001) } \\
\text { Fogg et al. }(2001) \\
\text { Boeuf et al. }(2014) \\
\text { Colombo et al. }(2015) \\
\text { Koch and Siering (2015) } \\
\text { Gafni et al. (2018) }\end{array}$ & $\begin{array}{l}\text { - Picture of the project owner boosts the probability of } \\
\text { obtaining success; } \\
\text { - Name of entrepreneurs on the pages of projects are } \\
\text { positively and significantly related to CF success; } \\
\text { - Presenting authentic people from a company in a campaign } \\
\text { gives a "real-world feeling" and enhances credibility. }\end{array}$ \\
\hline Number of backers & $\begin{array}{l}\text { Bikhchandani et al. (1992) } \\
\text { Shen et al. (2010) } \\
\text { Herzenstein et al. (2011) } \\
\text { Lee et al. (2011) } \\
\text { Lee and Lee (2012) } \\
\text { Zhang and Liu (2012) } \\
\text { Colombo et al. (2015) } \\
\text { Agrawal et al. (2015) } \\
\text { Hobbs et al. (2016) } \\
\text { Wang and Tu (2016) } \\
\text { Gangi and Daniele (2017) } \\
\text { Kuppuswamy and Bayus (2018) } \\
\text { Mezei (2018) }\end{array}$ & $\begin{array}{l}\text { - Evidence of a strong herding behaviour; } \\
\text { - Higher participation rate attracts more bids; } \\
\text { - The number of backers is a positive predictor of the } \\
\text { probability of success of a CF campaign; } \\
\text { - Strong community support for a venture signals that the project } \\
\text { is perceived as having high quality; } \\
\text { - Funders' propensity to invest in a given artist increases as } \\
\text { capital on the platform accumulates; } \\
\text { - The success of a CF campaign depends highly on the early } \\
\text { support given by backers; } \\
\text { - Past investments made by other backers may increase the } \\
\text { propensity to fund; } \\
\text { - The dynamic pattern of backer support over the project } \\
\text { funding cycle is U-shaped. }\end{array}$ \\
\hline Founder's team & Lagazio and Querci (2018) & $\begin{array}{l}\text { - Projects that present a large number of team members had a } \\
\text { higher probability of succeeding in fundraising }\end{array}$ \\
\hline Previous experience of the founder & $\begin{array}{l}\text { Courtney et al. (2017) } \\
\text { Zhou et al. (2018) } \\
\text { Janku and Kucerova }(2018) \\
\text { Koch and Siering }(2015 ; 2019)\end{array}$ & $\begin{array}{l}\text { - Founders that have a higher number of previous projects } \\
\text { funded might increase the probability of having more } \\
\text { success in the subsequent projects' campaigns }\end{array}$ \\
\hline
\end{tabular}

Source: Authors' own elaboration.

\section{METHODOLOGY}

This study focuses on the projects launched by entrepreneurs to raise money from backers to start their new venture within a limited time window, providing prospective investors with different reward schemes. The backers interested in a certain project choose an appropriate reward scheme and pay the backing prices to support the project. A project will be funded if the total money of committed purchases from backers exceeds a specified goal within a predetermined time window.

The purpose of the investigation is to empirically examine the influence of social media and e-WOM on the success of a CF campaign. To that purpose, we extracted a unique dataset from the Indiegogo platform. Indiegogo was created, in 2008, in the United States (San Francisco) and according to the information displayed on their website since the beginning of the operations the platform has helped more than 800,000 innovative ideas come to life. The number of people that visit the platform is impressive (ten million each month), geographically diversified (235 countries and territories) with around 19,000 campaigns launched by month (www. indiegogo.com). Projects fall into three main groups: i) Tech and Innovation; ii) Creative Works; iii) Community Projects. The first group includes audio, camera gear, education, energy \& green tech, fashion \& wearables, food \& beverages, health \& fitness, home, phones \& accessories, productivity, transportation, and travel \& outdoors. The second group encompasses art, comics, dance \& theatre, film, music, photography, podcasts, blogs \& vlogs, tabletop games, videogames, web series \& TV shows, and writing \& publishing. The last group includes culture, environment, human rights, local businesses, and wellness. For empirical analysis we have excluded the last group as the projects are mainly related to social causes and social CF, that is led by different motivations.

To perform the study, secondary data about different characteristics of the founder and the project were collected from the platform IndieGoGo (www.IndieGoGo.com). Then, we proceed to the process of content analysis by analysing a random strat- 
ified sample of the projects displayed on the platform between March and September of 2019. The sample includes both successful and unsuccessful projects and is limited to two strata - technology, and arts and culture. The final sample was composed of 125 technological and 125 arts and culture projects, that were conjointly analysed, given the research aims.

The data were codified and examined using several statistical techniques from the software package IBM SPSS, version 24. Specifically, firstly, we have employed descriptive statistics, that were followed by correlation analysis to detect problems of multicollinearity. After some tests, we proceed to the OLS multiple regression analysis to assess the causal effect of the different variables in the success rate of the project. The model to be used is presented in the next section.

\section{MODEL}

To estimate a response model, we use a multiple regression analysis (OLS). This is a statistical technique that allows a researcher to analyse the impact of each independent variable in an output. In this case, the formula assumes that the outcome (dependent variable), the success rate of a project, is a function of the factors (independent variables). The variables regarding the rate of success (SUC), the total amount of the pledging goal (AMOU) the number of likes on Facebook's page (LIKE) and the number of online comments (COMM) used in the analysis were logarithmised to render the distribution nearly normal.

The generic equation is the following:

$\log ($ SUC $)=a+\beta 1 \operatorname{LogLIKE}+\beta 2 \log C O M M+\beta 3$ IDD $+\beta 4$ PROT $+\beta 5$ UPD $+\beta 6$ NAT $+\beta 7 \log A M O U+\beta 8$ PRES $+\beta 9 \operatorname{LogBACK}+\beta 10 \mathrm{TEAM}+\beta 11 \mathrm{PREV}+\mathrm{e}$

In this model, the dependent variable is the Success of a CF project (SUC). This variable takes the value given by the percentage of the pledging goal that could be above or below $100 \%$. The projects that attain values above $100 \%$ (attain the pledging goal) are considered successful, while projects with values below $100 \%$ are considered a failure. The higher the value above $100 \%$, the more successful is the project.

The key independent variables related to social media and e-WOM are:

- The logarithm of the number of Facebook friends (LogLIKE) is the number of likes that the Facebook page of the campaign displays;

- The logarithm of the number of comments (LogCOMM) is the number of comments posted by the followers of the project in the project feed of the CF platform, in a logarithmised form.

The key independent variables related to the project are:

- Length of the video pitch (VIDD), measured in minutes;

-Depth of the project description (PROT) is a dummy variable that takes the value of 1 when there is a detailed description that allows deriving a prototype of the project (such as images, an explanation of the evolution of the product/idea); and 0 otherwise; - Availability of project updates (UPD) is a dummy variable that takes the value of 1 when have been registered updates for the project and 0 otherwise;
- Typology of the project (NAT) is a dummy variable and takes value 1 for technology projects and 0 for arts and culture projects;

- The logarithm of the amount of pledging goal (LogAMOU) is the total amount of the pledging goal, in US dollars, in a logarithmised form.

The key independent variables related to the founder are:

- Presentation of the project's promoter (PRES) is a dummy variable that takes the value of 1 when the founder of the project appear (name and photo) and 0 otherwise;

- The logarithm of the number of backers (LogBACK) includes the number of backers registered on the platform for a given project, in a logarithmised form;

- Nature of the founders (TEAM) is a dummy variable with 1 for a campaign developed by a team and 0 by an individual;

- Previous experience of the entrepreneur (PREV): it is a dummy variable that when the promoter has previous experience on a CF campaign the value is 1 and 0 otherwise.

\section{RESULTS}

The analysis of Table 5 shows that the dependent variable that measures the success of each CF campaign in the Indiegogo platform has a minimum value of 4 and a maximum value of 20600. Overall, of the 250 campaigns inspected we can see that at least one of them was exceptionally successful surpassing the pledging goal by far $(20600 \%)$, while on the other extreme one campaign has failed to obtain only $4 \%$ of the pledging goal. To avoid problems of skewness of the data, the variable LogSUC presents the values in a logarithmised form.

Table 5

Descriptive Statistics

\begin{tabular}{lrrrr}
\hline \multicolumn{1}{c}{ Variables } & \multicolumn{1}{c}{ Mean } & Standard Deviation & Minimum & Maximum \\
\hline SUC & 846.34 & 2051.668 & 4 & 20600 \\
LogSUC & 5.43 & 1.55 & 1.39 & 9.93 \\
LIKE & 24068.23 & 124743.47 & 2 & 1315968 \\
Log LIKE & 7.0294 & 2.25665 & 0.69 & 14.09 \\
COMM & 364.61 & 1704.85 & 0 & 20647 \\
Log COMM & 2.0731 & 2.58394 & 0 & 9.94 \\
VIDD & 2.09 & 1.64 & 0 & 11 \\
PROT & 0.78 & 0.418 & 0 & 1 \\
UPD & 0.76 & 0.425 & 0 & 1 \\
NAT & 0.52 & 0.500 & 0 & 1 \\
AMOU & 35598.53 & 81306.02 & 500 & 669086 \\
Log AMOU & 9.2821 & 1.63452 & 6.21 & 17.17 \\
PRES & 0.63 & 0.484 & 0 & 1 \\
BACK & 2400.57 & 6712.49 & 3 & 46285 \\
Log BACK & 5.4616 & 2.16049 & 1.10 & 10.74 \\
TEAM & 0.58 & 0.494 & 0 & 1 \\
PREV & 0.32 & 0.467 & 0 & 1 \\
\hline
\end{tabular}

Note: $\mathrm{N}=250$.

Source: Authors' own elaboration. 
The CF campaign facebook page got on average 24,068 Likes; some projects have only 2 likes on Facebook, whether others obtained an impressive number of $1,315,968(M=24,000)$. The number of comments on the project feed also has a high variability between projects, ranging from the absence of comments at all observed in some projects to a maximum of 20,647 comments $(M=364.61)$.

The independent variables VIDD (video duration) has a maximum of 11 minutes and a mean of 2 minutes. The pledging goal for the projects is positioned between 500 and 669,086 US dollars ( $M=36,000 \mathrm{USD})$. The number of backers varies between 3 and 46,285 $(M=2,400)$.
The correlation matrix for the variables used in the study is provided in Table 6. An inspection of the different correlations shows low coefficients in most of the variables, although some values merit our attention as some of them are higher than 0.50 . Consequently, we determine if there were multicollinearity problems with the independent variables by applying the methods recommended by Hair et al. (1995) and O'Brien (2007). The variance inflation factors (VIF) found for the different variables are all well below the threshold value of 10 , and most of them below 2 . Therefore, we proceed with our analysis as multicollinearity was not a problem.

Table 6

Correlation Matrix

\begin{tabular}{|c|c|c|c|c|c|c|c|c|c|c|c|c|}
\hline Variables & (1) & (2) & (3) & (4) & (5) & (6) & (7) & (8) & (9) & (10) & (11) & (12) \\
\hline $\begin{array}{l}\text { LogSUC } \\
\text { (1) }\end{array}$ & 1 & $\begin{array}{c}0.462 \\
(* *)\end{array}$ & $\begin{array}{c}0.692 \\
\left({ }^{* *}\right)\end{array}$ & 0.049 & $\begin{array}{c}0.313 \\
\left({ }^{*}\right)\end{array}$ & $\begin{array}{c}0.299 \\
(* *)\end{array}$ & $\begin{array}{l}0.47 \\
(* *)\end{array}$ & $\begin{array}{c}0.236 \\
(* *)\end{array}$ & 0.03 & $\begin{array}{c}0.723 \\
\left({ }^{*}\right)\end{array}$ & $\begin{array}{l}0.36 \\
(* *)\end{array}$ & $\begin{array}{c}0.244 \\
(* *)\end{array}$ \\
\hline $\begin{array}{l}\text { LogLIKE } \\
\text { (2) }\end{array}$ & $\begin{array}{c}0.462 \\
\left({ }^{*}\right)\end{array}$ & 1 & $\begin{array}{c}0.574 \\
\left({ }^{*}\right)\end{array}$ & $\begin{array}{c}0.207 \\
(* *)\end{array}$ & $\begin{array}{c}0.128 \\
\left({ }^{*}\right)\end{array}$ & $\begin{array}{c}0.311 \\
\left({ }^{*}\right)\end{array}$ & $\begin{array}{c}0.153 \\
\left({ }^{*}\right)\end{array}$ & $\begin{array}{c}0.479 \\
(* *)\end{array}$ & 0.006 & $0.616^{\star}\left(^{\star}\right)$ & $\begin{array}{c}0.256 \\
\left({ }^{*}\right)\end{array}$ & $\begin{array}{c}0.155 \\
\left({ }^{*}\right)\end{array}$ \\
\hline $\begin{array}{l}\text { LogCOMM } \\
\text { (3) }\end{array}$ & $\begin{array}{c}0.692 \\
(* *)\end{array}$ & $\begin{array}{c}0.574 \\
(* *)\end{array}$ & 1 & $\begin{array}{c}0.247 \\
(* *)\end{array}$ & $\begin{array}{c}0.222 \\
\left({ }^{*}\right)\end{array}$ & $\begin{array}{c}0.374 \\
\left({ }^{*}\right)\end{array}$ & $\begin{array}{c}0.374 \\
(* *)\end{array}$ & $\begin{array}{c}0.627 \\
(* *)\end{array}$ & 0.049 & $\begin{array}{c}0.863 \\
\left({ }^{* *}\right)\end{array}$ & $\begin{array}{c}0.393 \\
\left({ }^{*}\right)\end{array}$ & $\begin{array}{l}0.20 \\
(* *)\end{array}$ \\
\hline $\begin{array}{l}\text { VIDD } \\
(4)\end{array}$ & 0.049 & $\begin{array}{c}0.207 \\
(* *)\end{array}$ & $\begin{array}{c}0.247 \\
(* *)\end{array}$ & 1 & 0.075 & $\begin{array}{l}0.30 \\
(* *)\end{array}$ & 0.012 & $\begin{array}{l}0.44 \\
(* *)\end{array}$ & $\begin{array}{c}0.153 \\
\left({ }^{*}\right)\end{array}$ & $\begin{array}{c}0.296 \\
\left({ }^{*}\right)\end{array}$ & 0.069 & -0.02 \\
\hline $\begin{array}{l}\text { PROT } \\
\text { (5) }\end{array}$ & $\begin{array}{c}0.313 \\
(* *)\end{array}$ & $\begin{array}{c}0.128 \\
\left({ }^{*}\right)\end{array}$ & $\begin{array}{c}0.222 \\
(* *)\end{array}$ & 0.075 & 1 & 0.085 & $\begin{array}{c}0.237 \\
(* *)\end{array}$ & $\begin{array}{c}0.156 \\
\left({ }^{*}\right)\end{array}$ & $\begin{array}{c}-0.235 \\
(* *)\end{array}$ & $\begin{array}{c}0.265 \\
(* *)\end{array}$ & $\begin{array}{c}0.268 \\
(* *)\end{array}$ & 0.101 \\
\hline $\begin{array}{l}\text { UPD } \\
(6)\end{array}$ & $\begin{array}{c}0.299 \\
(* *)\end{array}$ & $\begin{array}{c}0.311 \\
(* *)\end{array}$ & $\begin{array}{c}0.374 \\
(* *)\end{array}$ & $\begin{array}{l}0.30 \\
(* *)\end{array}$ & 0.085 & 1 & 0.093 & $\begin{array}{l}0.36 \\
(* *)\end{array}$ & 0.118 & $\begin{array}{c}0.399 \\
(* *)\end{array}$ & 0.104 & 0.038 \\
\hline $\begin{array}{l}\text { NAT } \\
(7)\end{array}$ & $\begin{array}{l}0.47 \\
(* *)\end{array}$ & $\begin{array}{c}0.153 \\
\left({ }^{*}\right)\end{array}$ & $\begin{array}{c}0.281 \\
\left({ }^{*}\right)\end{array}$ & 0.012 & $\begin{array}{c}0.237 \\
\left({ }^{* *}\right)\end{array}$ & 0.093 & 1 & $\begin{array}{c}0.241 \\
\left({ }^{*}\right)\end{array}$ & $\begin{array}{c}-0.154 \\
\left({ }^{*}\right)\end{array}$ & $\begin{array}{c}0.326 \\
\left({ }^{* *}\right)\end{array}$ & $\begin{array}{c}0.398 \\
\left({ }^{*}\right)\end{array}$ & 0.07 \\
\hline $\begin{array}{l}\log A M O U \\
(8)\end{array}$ & $\begin{array}{c}0.236 \\
\left({ }^{* *}\right)\end{array}$ & $\begin{array}{c}0.479 \\
(* *)\end{array}$ & $\begin{array}{c}0.627 \\
\left({ }^{*}\right)\end{array}$ & $\begin{array}{l}0.44 \\
(* *)\end{array}$ & $\begin{array}{c}0.156 \\
\left({ }^{*}\right)\end{array}$ & $\begin{array}{l}0.36 \\
(* *)\end{array}$ & $\begin{array}{c}0.241 \\
(* *)\end{array}$ & 1 & 0.085 & $\begin{array}{c}0.678 \\
(* *)\end{array}$ & $\begin{array}{c}0.269 \\
(* *)\end{array}$ & -0.005 \\
\hline $\begin{array}{l}\text { PRES } \\
(9)\end{array}$ & 0.03 & 0.006 & 0.049 & $\begin{array}{c}0.153 \\
\left({ }^{*}\right)\end{array}$ & $\begin{array}{c}-0.235 \\
\left({ }^{* *}\right)\end{array}$ & 0.118 & $\begin{array}{c}-0.154 \\
\left({ }^{*}\right)\end{array}$ & 0.085 & 1 & 0.10 & -0.012 & -0.04 \\
\hline $\begin{array}{l}\text { LogBACK } \\
\text { (10) }\end{array}$ & $\begin{array}{c}0.723 \\
\left({ }^{* *}\right)\end{array}$ & $\begin{array}{c}0.616 \\
(* *)\end{array}$ & $\begin{array}{c}0.863 \\
\left({ }^{*}\right)\end{array}$ & $\begin{array}{c}0.296 \\
\left({ }^{* *}\right)\end{array}$ & $\begin{array}{c}0.265 \\
\left({ }^{* *}\right)\end{array}$ & $\begin{array}{c}0.399 \\
(* *)\end{array}$ & $\begin{array}{c}0.326 \\
(* *)\end{array}$ & $\begin{array}{c}0.678 \\
\left({ }^{* *}\right)\end{array}$ & 0.10 & 1 & $\begin{array}{c}0.418 \\
(* *)\end{array}$ & $\begin{array}{c}0.139 \\
\left({ }^{*}\right)\end{array}$ \\
\hline $\begin{array}{l}\text { TEAM } \\
\text { (11) }\end{array}$ & $\begin{array}{l}0.36 \\
(*)\end{array}$ & $\begin{array}{c}0.256 \\
\left({ }^{*}\right)\end{array}$ & $\begin{array}{c}0.393 \\
\left({ }^{*}\right)\end{array}$ & 0.069 & $\begin{array}{c}0.286 \\
\left({ }^{* *}\right)\end{array}$ & 0.104 & $\begin{array}{c}0.398 \\
\left({ }^{* *}\right)\end{array}$ & $\begin{array}{c}0.269 \\
\left({ }^{* *}\right)\end{array}$ & -0.12 & $\begin{array}{c}0.418 \\
\left({ }^{* *}\right)\end{array}$ & 1 & 0.092 \\
\hline $\begin{array}{l}\text { PREV } \\
(12)\end{array}$ & $\begin{array}{c}0.244 \\
\left({ }^{*}\right)\end{array}$ & $\begin{array}{c}0.155 \\
\left({ }^{\star}\right)\end{array}$ & $\begin{array}{l}0.20 \\
(* *)\end{array}$ & -0.022 & 0.101 & 0.038 & 0.07 & -0.005 & -0.04 & $\begin{array}{c}0.139 \\
(* *)\end{array}$ & 0.092 & 1 \\
\hline
\end{tabular}

Note: $\mathrm{N}=250$. Significance: $\left({ }^{\star *}\right) \mathrm{p}<0.01 ;\left({ }^{*}\right) \mathrm{p}<0.05$.

Source: Authors' own elaboration.

To assess the impact of each of the independent variables on the success rate of a CF campaign, we conducted multiple OLS regression analysis according to the general model presented before. To evaluate the impacts separately, we create four models: a full model contemplates all the variables, and three restricted models grouped the independent variables related with social media and e-WOM, the project and the founder. A global analysis of all the models shows that the coefficient of the adjusted $\mathrm{R}^{2}$ is high (between 0.736 and $0.314)$ and the values of Snedecor's F statistically significant $(p<0.01)$.
The empirical results for CF campaign success are presented in Table 7. The full model explains $73.6 \%$ of the variance that could be considered very effective at predicting the success of a CF campaign. Even if this model represents only a general exploratory investigation of the variables, it confirms their influence on the dependent variable. The results of Model 1 indicate that of the 11 variables under consideration, only VIDD, PRES and TEAM have no significant effects on CF success. The variables regarding the social media (LIKE) and the e-WOM 
$(\mathrm{COMM})$ are statistically significant $(p<0.10 ; p<0.05$, respectively) indicating that gaining comments and likes to the project increases the probability of success of the campaign.

Table 7

Results of the OLS multiple regression (dependent variable Log (SUC)

\begin{tabular}{lcccc}
\hline Variables & $\begin{array}{c}\text { Model 1 } \\
\text { (All } \\
\text { variables) }\end{array}$ & $\begin{array}{c}\text { Model 2 } \\
\text { (Digital } \\
\text { marketing } \\
\text { related } \\
\text { variables) }\end{array}$ & $\begin{array}{c}\text { Model 3 } \\
\text { (Project } \\
\text { related } \\
\text { variables) }\end{array}$ & $\begin{array}{c}\text { Model 4 } \\
\text { (Founder } \\
\text { related } \\
\text { variables) }\end{array}$ \\
\hline Intercept & $5.252^{* * *}$ & $4.169^{* * *}$ & $0.3211^{\star * *}$ & $2.751^{* * *}$ \\
LIKE & $0.078^{\star}$ & $0.097^{*}$ & & \\
COMM & $0.218^{* *}$ & $0.637^{\star *}$ & & \\
VIDD & -0.05 & & -0.068 & \\
PROT & $0.103^{* *}$ & & $0.196^{* * *}$ & \\
UPD & $0.067^{*}$ & & $0.247^{* * *}$ & \\
NAT & $0.257^{* * *}$ & & $0.405^{* * *}$ & \\
AMOU & $-0.482^{* *}$ & & 0.053 & \\
PRES & 0.055 & & & -0.032 \\
BACK & $0.696^{* * *}$ & & & $0.681^{* * *}$ \\
TEAM & 0.048 & & & -0.062 \\
PREV & $0.064^{*}$ & & & $0.143^{* *}$ \\
Adjusted R2 & 0.736 & 0.481 & 0.314 & 0.541 \\
F & $64.048^{* * *}$ & $116.512^{* *}$ & $23.743^{* * *}$ & $74.401^{* * *}$ \\
\hline
\end{tabular}

Note: $\left({ }^{* * *}\right) \mathrm{p}<0.01 ;\left(^{* *}\right) \mathrm{p}<0.05 ;\left(^{*}\right) \mathrm{p}<0.10$.

Source: Authors' own elaboration.

The length of the video, although with the correct signal has no statistical significance, meaning that excessive duration of the video pitch could be more harmful than positive to the campaign. The non-significance of the variable TEAM implies that a project conducted by a single or a team of entrepreneurs do not enhance or reduce the rate of success of the campaign. The same applies to PRES regarding the founder's presentation. Additionally, the full model shows that when all variables are included the critical factors for a successful campaign of CF are the existence of an extensive description of the project $(p<0.05)$, the appropriate updates that are added to the project $(p<0.10)$, the technological nature of the project $(p<0.01)$, the number of funders that already invested in the project (backers) $(p<0.01)$, the previous experience of the founder on the platform $(p<0.10)$. The amount of the project is inversely related to the success of the campaign, meaning that the higher the pledging goal for a project, the lower is the probability of success $(p<0.05)$.

The partial Model 2 consists of just the variables related to social media and eWOM, show consistency with the full model. The decrease in the adjusted $\mathrm{R}^{2}$ over Model $1(0.255)$ is also significant $(\mathrm{p}<0.01)$ but acceptable as the partial model maintain the predictive power ( $48.1 \%$ of the variance explained). According to the results, the likes shared on Facebook's page (LIKE) and the comments posted on the platform about the project (COMM) seems to be relevant ( $p<0.05 ; p<0.01$, respectively) to attract more funders to the project. This evidence strongly supports hypothesis $\mathrm{H} 1$ and $\mathrm{H} 2$.

Model 3 evaluate the sole impact of the characteristics of the project on the success of the campaign. The decrease in the ad- justed $\mathrm{R}^{2}$ over Model $1(0.422)$ is also significant $(p<0.01)$, but acceptable as $31.4 \%$ of the variance is explained by the model. As in the full model, the existence of a detailed description of the project (PROT) increases the chance of funding $(p<0.01)$. The same occurs with the posting of updates to the project (UPD) and the technological nature of the project (NAT) that are both statistically significant $(p<0.01)$. On the contrary, none of the variables related to the pledging goal fixed for a project (AMOU) and the length of the video pitch (VIDD) was statistically significant. These results show that only variables PROT, UPD and NAT contribute significantly to the success rate of the campaign and thus partially supporting $\mathrm{H} 3$.

Model 4 drops the variables related to the project and the social media and e-WOM to evaluate the impact of founder related factors on the success of the campaign. The decrease in the adjusted $\mathrm{R}^{2}$ over Model $1(0.195)$ is also significant $(p<0.01)$ and effective at predicting the success of a CF' campaign as the variance explained is $54.1 \%$. To attract more funds to their projects, founders have to rely on the backers (BACK) and the herding effect $(p<0.01)$ and in the previous experience (PREV) on the platform with other ventures. The variables PRES and TEAM show no statistical significance. Therefore, as only variables BACK and PREV significantly contribute to the success rate of the campaign, the hypothesis $\mathrm{H} 4$ is only partially confirmed.

\section{DISCUSSION AND PRACTICAL IMPLICATIONS}

Several interesting results were found regarding the factors that might increase the rate of success of a CF campaign. Perhaps the most noteworthy finding in this study is that the participation in online communities (Facebook) and the e-WOM generated by the comments posted on the website of the project are important to be successful. This corroborates with the basic conclusions of the studies which found that that a campaign benefits from user-generated e-WOM (online comments) and social media (Facebook shares) (e.g. Beier and Wagner 2015; Borst et al. 2017; Kaminski et al. 2018; Lu et al. 2014). However, the intensity of the impact of e-WOM is higher than the social media effect. Clearly, the relative importance of the e-WOM suggests that lack of information directly related to the quality of the project may lead prospective backers to rely on e-WOM (Belleflamme et al. 2015). Within this perspective, the comments made about a project through social networks can enhance social interaction and connectivity generating a positive e-WOM (Kaur and Gera 2017) and therefore attracting more supporters to the campaign.

The effect of social media on the success rate of the campaign seems to be more limited than anticipated by other studies. Even though a large numbers of friends on online social networks (Mollick and Kuppuswamy 2014) or the size of a fundraiser's personal network (number of Facebook connections) (Mollick 2014) have long been associated with the success of CF campaigns. However, it should be noted that as mentioned by Summers et al. (2016) and Borst et al. (2017), the influence of social media on the investors decision-making process could be shaped by the type of platforms used.

Also, social buzz (especially Facebook shares) and social media activities positively influence project backing (Thies et al. 2014; 
Lu et al. 2014; Hong et al. 2015). Therefore, social media should be frequently used by the promoters of the project to spread information, ask for support and resources, and share project updates (Hui et al. 2014). Facebook, as the main social network, is particularly important to promote the project by sharing, discuss, and communicate with prospective backers.

The positive contribution of social media and eWOM on the campaign success could either derive from the massive communication that is established with a broader audience, only made possible through the use of multiple digital communication platforms.

Even so, the specific impact of eWOM on the ability to obtain financial support to the project could be justified by the "independent messages", that are produced by others and not by the promoter. As the comments generated by eWOM are not controlled by the founder, apparently create a very positive impact on crowdfunders' behavior and decision-making process.

Further, the use of social media and eWOM could signal some additional transparency to potential investors (Sahaym et al. 2019), since the founder is willing to display more information to people and accept to be exposed to higher public scrutiny, to those who participate in social platforms. In a scenario of information asymmetry that CF involves, this signalling effect could be especially important to convince investors to give support to a specific campaign, over many others for which very little information is available.

The findings suggest some herd behavior of the investors that is triggered by the buzz caused by a higher number of comments on social media, as stated by Borst et al. (2017). Further, the study highlights the importance of social media and eWOM as predictors of a campaign success rate. As mentioned before, the partial model used (Model 1), explains $48.1 \%$ of all data variance, while the full model that comprised eleven (11) independent variable has an explanatory power of $73.6 \%$. Thus, the investigation suggests that to be successful in the CF campaign it is imperative to pay a careful attention to the formulation of the fundraising operation (project-related attributes and founders profile), as well as to the design of the digital communication strategy.

The results regarding the project related variables and the positive impact on the rate of success of a CF campaign are in line for the importance of displaying detailed information about the product (prototype, pictures, photos, schemes) (Koch and Siering 2015, 2019; Hobbs et al. 2016; Hossain and Oparaocha 2017). Also, the importance of posting updates about the project has been confirmed as generating a positive effect on the success of the CF campaign (Mollick 2014; Cho and Kim 2017; Kuppuswamy and Bayus 2018; Shahab et al. 2019). The same happens with the technological nature of the projects that are more valued by crowdfunders that seem to feel more comfortable in supporting technological projects rather than cultural ones (Hörisch 2015; Chan et al. 2018). The variables amount of pledging goal and length of the video pitch are negligible (non-statistical significance). Conversely, the empirical literature reports a negative impact for higher pledging goals (Mollick 2014; Frydrych et al. 2014; Colombo et al. 2015; Kaartemo 2017) that is validated in the full model but not in the second, thus meaning that no definitive conclusion can be obtained. On the other hand, a positive effect for the video pitch was expected (Jiang and Benbasat 2007; Mollick 2014; Koch and Siering 2019) but not confirmed. A possible explanation is that the variable measures the duration of the video pitch instead of its availability on the platform, and therefore the negative effect is for longer rather than shorter videos that might be effective in attracting potential funders.

Concerning the founders' profile, the results indicate a positive effect of backers' support and previous experience. These two predictive impacts are in line with the literature. Firstly, the positive impact of the number of backers suggests that each investor is not completely independent, but is influenced by the behaviour of other crowdfunders (Lee et al. 2011). Secondly, the previous experience of the founder is recognised by the empirical literature as significant for the success of the CF campaign (Courtney et al. 2017; Zou et al. 2018; Janku and Kucerova 2018; Koch and Siering 2015, 2019). The presentation of the founder and the single or collective nature of the founder is not supported by the data. The first finding is surprising as most of the literature argues that founders should present themselves to reduce uncertainty, increase transparency (Koch and Siering 2015) and credibility (Egger 2001; Fogg et al. 2001). One possible explanation is that prospective investors put more emphasis on the number of backers (herding effect) and the previous experience of the founder than on the way the founder presents himself to the audience or the elements of the team.

From the findings it is possible to derive some important practical implications to people who are thinking about launching a CF campaign. First of all, to be successful in getting funds through CF platforms requires a constant presence in social media to generate social buzz and engage with prospective investors. Herein, it is highly recommended the definition of an integrated digital marketing strategy conducted by professionals or people technically prepared. The results pointed out that crowdfunding campaigner creators should make use of direct pieces of communication, since people (the crowd) positively values the provision of regular but also brief information in order to generate user content word of mouth. Also, entrepreneurs' commitment to potential investors, made through regular interaction and information provision, is a strategic asset that entrepreneurs should bear in mind once they had decided to use crowdfunding as a vehicle for funding their projects.

Another practical implication is the critical role that communication plays on CF success. The communications should be held internally, trough the elaboration of communication material, and the constant interaction through the provision of regular updates. However, to be able to attract more funds entrepreneurs have to stimulate "an external communication", through the generation of comments by supporters, that have a more powerful impact on the "crowd behavior", than the formal information prepared and controlled by the founder. Being able to create a digital debate around the campaign and an emotional commitment to the project will be critical to the success of the campaign.

Another practical implication that could be derived is that for taking advantage of all the social media potential it is important to get an in-depth knowledge of the audience the campaign intents to engage, that could be more sensitive to the work developed in some social platforms than others. 


\section{CONCLUSIONS}

Crowdfunding has been recognised as a very promising fundraising tool for new ventures. However, not all campaigns have the same potential in terms of resource mobilisation, since some of them are successful in terms of funds collected and others not. In this scenario, it is critical to have a deeper understanding of the factors that are able to drive the success of a given campaign, specifically social media and e-WOM.

The results indicate that it is possible to find an explanation for the different levels of success of reward CF campaigns based on the analysis of network factors, the characteristics of the project and its founder. The results show that social media and, especially, e-WOM have a positive impact on the success rate of a campaign. Also, factors related to the project (detailed information of the future product, project updates, and the nature of the project, specifically if it has a technological orientation) have demonstrated a positive impact. By contrast, the length of the video pitch and a higher pledging goal affects negatively the campaign success. In the founder's profile, the most important factors were the number of backers supporting the project and the existence of a previous campaign on the platform, while the presentation of the founder and his team have been devaluated.

As can be seen by the results, the success of a CF campaign is based on multiple criteria that include the presence in social platforms, the digital networking of the founder with its followers and backers, the characteristics of the project as well as the founder profile. Thus, a deeper understanding of the critical success factors of a campaign should include and not isolate all the elements that have been studied.

The results obtained suggest that in the investor's decision-making process, potential funders (crowdfunders) highlight the importance of the attributes that signal the quality of the project for which funds are called, and thus mitigate some of the risks arising from information asymmetry. The research carried out indicate that the fears about information are major constrain of $\mathrm{CF}$ although the reward-based CF was a non-investment model.

The investigation assessed the contribution of social media and eWOM on a CF campaign success, regardless of the content of the messages shared. In the future, it would be positive to separate the effect of different types of buzz (positive or negative comments), as well as evaluating the impact of different kind of traffic (such as organic and paid). In the study of social media, we have considered the use of Facebook, as it is one of the most important and researched social platforms. Even so, the use of a unique social platform is a limitation of the study. In the future, it would be interesting to extend the research model to other social platforms.

The investigation unfolds some important issues that are worthy of being further studied. One example of that is the role played by entrepreneurs' previous experience on the success of CF campaigns and how this past experience can leverage the fundraising outcomes. Some qualitative research (in-depth interviews) would probably bring new insights into this issue.

In the future, it would be worthy of extending the investigation to other platforms and countries, since most of the empirical studies have been performed under the most well-known American platforms, such as Kickstarter or Indiegogo. It would be interesting to study the success factors of CF campaigns in other platforms of more peripheral countries and with different economic development levels. It would also be quite interesting to understand if the major factors that influence CF success are the same in different business models of CF. As the research suggests that investors are highly concerned with asymmetry information risks, it would be worthy of performing additional research on the topic, and study in-depth the main fears affecting potential investors.

\section{REFERENCES}

Aggarwal, R., Gopal, R., Gupta, A., and Singh, H., 2012. Putting Money Where the Mouths Are: The Relation between Venture Financing and Electronic Word-of-Mouth. Information Systems Research, 23, 976-992.

Agrawa, A., Catalini, C. and Goldfarb, A., 2015. Crowdfunding: geography, social networks, and the timing of investment decisions. Journal of Economics \& Management Strategy, 24(2), 253-274.

Ahlers, G.K.C., Cumming, D., Gunther, C. and Schweizer, D., 2015. Signaling in equity crowdfunding. Entrepreneurship Theory and Practice, 39(4), 955-980.

André, K., Bureau, S., Gautier, A. and Rubel, O., 2017. Beyond the Opposition Between Altruism and Self-interest: Reciprocal Giving in Reward-Based Crowdfunding. Journal of Business Ethics, 146, 313-332.

Baumgardner, T., Neufeld, C., Huang, P., Sondhi, T., Mursalin, F. and Talha, A., 2017. Crowdfunding as a Fast Expanding Market for the Creation of Capital and Shared Value. Thunderbird International Business Review, 59(1), 115-126.

Beier, M. and Wagner K., 2015. Crowdfunding Success: A Perspective from Social Media and E-Commerce. Paper presented at the International Conference on Information Systems (ICIS), Fort Worth, USA, December.

Belleflamme, P., Lambert, T. and Schwienbacher, A., 2014. Crowdfunding: Tapping the right crowd. Journal of Business Venturing, 29(5), 585-609.

Belleflamme, P., Omrani, N. and Peitz, M., 2015. The Economics of Crowdfunding Platforms. Information Economics and Policy, 33, 11-28.

Bi, S., Liu, Z. and Usman, K., 2017. The influence of online information on investing decisions of reward-based crowdfunding. Journal of Business Research, 71, 10-18.

Bikhchandani, S., D. Hirshleifer, and I. Welch, 1992. A Theory of Fads, Fashion, Custom, and Cultural-Change as Informational Cascades. Journal of Political Economy, 100(5), 457-486.

Block, J., Hornuf, L. and Moritz, A., 2018. Which updates during an equity crowdfunding campaign increase crowd participation? Small Business Economics, 50, 3-27.

Boeuf, B., Darveau, J., and Legoux, R., 2014. Financing creativity: Crowdfunding as a new approach for theatre projects. International Journal of Arts Management, 16(3), 33-48.

Borst, I., Moser, C., and Ferguson, J., 2017. From friendfunding to crowdfunding: Relevance of relationships, social media, and platform activities to crowdfunding performance. New Media \& Society, 20(4), 1396-1414.

Chan, C. S. R., Park, H. D., Patel, P. and Gomulya, D., 2018. Reward-based crowdfunding success: decomposition of the project, product category, entrepreneur, and location effects. Venture Capital, 20(3), 285-307.

Chevalier, J. A. and Mayzlin, D., 2006. The effect of word-of-mouth on sales: online book reviews. Journal of Marketing Research, 43(3), 345-354.

Cho, M., and Kim, G., 2017. A cross-cultural comparative analysis of crowdfunding projects in the United States and South Korea. Computers in Human Behavior, 72, 312-320.

Choi, Y. K., Seo, Y. and Yoon, S., 2017. E-WOM messaging on social media: social ties, temporal distance, and message concreteness. Internet Research. 27(3), 495-505. 
Choy, K. and Schlagwein, D., 2016. Crowdsourcing for a better world: on the relation between IT affordances and donor motivations in charitable crowdfunding. Information Technology \& People. 29(1), 221-247.

Colombo, M. G., Franzoni, C. and Rossi-Lamastra, C., 2015. Internal social capital and the attraction of early contributions in crowdfunding. Entrepreneurship Theory and Practice, 39(1), 75-100.

Courtney, C., Dutta, S. and Li, Y., 2017. Resolving information asymmetry: signaling, endorsement, and crowdfunding success. Entrepreneurship Theory and Practice, 41(2), 265-290.

Cruz, J., 2018. Beyond financing: crowdfunding as an informational mechanism. Journal of Business Venturing, 33, 371-393.

Cruz, J. V., 2017. The Economics of Crowdfunding: Entrepreneurs' and Platforms' Strategies. Sociology. Université Sorbonne, Paris Cité.

Egger, F. N., 2001. Affective Design of E-Commerce User Interfaces: How to Maximise Perceived Trustworthiness. In: Proceedings of the Conference on Affective Human Factors Design (CAHD). Singapore.

European Comission, 2015. Crowdfunding from an investor perspective. Oxera, European Union. ISBN: 978-92-79-46659-5.

Fogg, B. J., Marshall, J., Laraki, O., Osipovich, A., Varma, C., Fang, N., Paul, J., Rangnekar, A.,Shon, J., Swani, P. and Treinen, M., 2001. What Makes Web Sites Credible? A Report on a Large Quantitative Study. In: Proceedings of the CHI Conference on Human Factors in Computing Systems. Seattle: USA.

Forgas, J., Williams, K. and Laham, S., 2005. Social motivation: introduction and overview. In Williams, K.D. \& Laham, S.M. (Eds), Social Motivation: Conscious and Unconscious Processes, Cambridge University Press, Cambridge, 1-15.

Frydrych, D, Bock, A. J., Kinder, T., and Koeck, B., 2014. Exploring Entrepreneurial Legitimacy in Reward-Based Crowdfunding. Venture Capital: An International Journal of Entrepreneurial Finance, 16 (3), 247-269.

Gafni, H., Marom, D. and Sade, O., 2018. Are the life and death of an early-stage venture indeed in the power of the tongue? Lessons from online crowdfunding pitches. Strategic Entrepreneurship Journal, 13, 3-23.

Gajda, O., and Mason, N., 2013. Crowdfunding for Impact in Europe and the USA. European Crowdfunding White Paper, 1-24. Available at: http:// eurocrowd.org/wp-content/blogs.dir/sites/85/2013/12/20131220_ ECN_Toniic_CrowdfundingForImpact.pdf

Gangi, F., and Daniele, L. M., 2017. Success drivers of reward-based crowdfunding: conceptual framework and empirical evidence. EURAM Conference 2017: Making Knowledge Work. 21-24 June, Glasgow, Scotland.

Gerber, E.M., and Hui, J., 2013. Crowdfunding: Motivations and Deterrents for Participation. ACM Transactions on Computer-Human Interactions, 20(6), 34-32.

Gerber, E., Hui, J. and Kuo, P., 2012. Crowdfunding: Why people are motivated to post and fund projects on crowdfunding platforms. CSCW Workshop. Available at: http://www.juliehui.org/wpcontent/ uploads/2013/04/CSCW_Crowdfunding_Final.pdf

Gierczak, M. M., Bretschneider, U., Haas, P. Blohm, I. and Leimeister, J. M., 2015. Crowdfunding - Outlining the New Era of Fundraising. In: Gajda, O. \& Brüntje, D. (Eds.), Crowdfunding in Europe - State of The Art in Theory And Practice, FGF Studies in Small Business and Entrepreneurship (pp. 7-23). Cham: Springer Science + Business Media.

Giudici, G., Massimiliano, G. and Rossi-Lamastra, C., 2017. Reward-based crowdfunding of entrepreneurial projects: the effect of local altruism and localised social capital on proponents' success. Small Business Economics, 50(2), 307-324.

Hair, J. F. Jr, Anderson, R. E., Tatham, R. L. and Black, W. C., 1995. Multivariate data analysis: with readings. Fourth Edition, New Jersey, Prentice Hall.

Hennig-Thurau, T., Gwinner, K., Walsh, G., and Gremler, D., 2004. Electronic word-of-mouth via consumer-opinion platforms: What motivates consumers to articulate themselves on the internet? Journal of Interactive Marketing, 18(1), 38-52.
Herzenstein, M., Dholakia, U. M. and Andrews, R.L., 2011. Strategic Herding Behavior in Peer-to-Peer Loan Auctions. Journal of Interactive Marketing, 25(1): 27-36.

Hobbs, J., Grigore, G. and Molesworth, M., 2016. Success in the management of crowdfunding projects in the creative industries. Internet Research, 26(1), 146-166.

Hommerová, D., 2020. Crowdfunding as a new model of nonprofit funding. In I. Garcia-Rodriguez \& M. E. Romero-Merino (Eds.), Financing Nonprofit Organizations (chapter 13). London, Routledge.

Hörisch, J., 2015. Crowdfunding for Environmental Ventures: An Empirical Analysis of the Influence of Environmental Orientation on the Success of Crowdfunding Initiatives. Journal of Cleaner Production, 107, 636-645.

Hong, Y., Hu, Y. and Burtch, G., 2015. How does social media affect contribution to public versus private goods in crowdfunding campaigns? Thirty Sixth International Conference on Information Systems (ICIS), Fort Worth, USA.

Hossain, M. and Oparaocha, G. O., 2017. Crowdfunding: motives, definitions, typology and ethical challenges. Entrepreneurship Research Journal, 7(2), 1-14.

Hui, J., Greenberg, M. D. and Gerber, E. M., 2014. Understanding the Role of Community in Crowdfunding Work. Proceedings of the 17th Conference on Computer Supported Cooperative Work (CSCW) 62-74.

Janku, J. and Kucerova, Z., 2018. Successful Crowdfunding Campaigns: the role of project specifics, competition and founders' experience. Czech Journal of Economics and Finance, 68(4), 351-373.

Jiang, Z. and Benbasat, I., 2007. The Effects of Presentation Formats and Task Complexity on Online Consumers' Product Understanding. MIS Quarterly, 31(3), 475-500.

Joshi, M., 2018. Crowdfunding For Startups in India, WEshkar, 24(1), 37-48.

Kaartemo, V., 2017. The elements of a successful crowdfunding campaign: A systematic literature review of crowdfunding performance. International Review of Entrepreneurship, 15(3), 291-318.

Kaminski, J., Hopp, C. and Lukas, C., 2018. Who benefits from the wisdom of the crowd in crowdfunding? Assessing the benefits of user-generated and mass personal electronic word of mouth in computer-mediated financing. Journal of Business Economics, 88(9), 1133-1162.

Kaur, H. and Gera, J., 2017. Effect of social media connectivity on success of crowdfunding campaigns. Procedia Computer Science, 122, 767-774.

Kietzmann, J. and Canhoto, A., 2013. Bittersweet! Understanding and Managing Electronic Word of Mouth. Journal of Public Affairs, 13(2), 146-159.

Koch, J. and Siering, M., 2015. Crowdfunding Success Factors: The Characteristics of Successfully Funded Projects on Crowdfunding Platforms. Twenty-Third European Conference on Information Systems (ECIS), Münster, Germany.

Koch, J. and Siering, M., 2019. The Recipe of Successful Crowdfunding Campaigns: an analysis of crowdfunding success factors and their interrelations. Electronic Markets, 29 (4), 661-679.

Kraus, S., Richter, C., Brem, A., Cheng, C-F. and Chang, M-L., 2016. Strategies for reward-based crowdfunding campaigns. Journal of Innovation \& Knowledge, 1(1), 13-23.

Kuppuswamy, V. and Bayus, B. L., 2018. A review of crowdfunding research and findings, Chapter 17. In Golder, P. and Mitra, D. (eds.), Handbook of Research on New Product Development, 361- 373, London, Edward Elgar Publishing.

Lagazio, C. and Querci, F., 2018. Exploring the multi-sided nature of crowdfunding campaign success. Journal of Business Research, 90, 318-324.

Lee, E. and Lee, B., 2012. Herding Behavior in Online P2P Lending: An Empirical Investigation. Electronic Commerce Research and Applications, 11(5), 495-503. 
Lee, E., Lee, B. and Chae, M., 2011. Herding Behavior In Online P2P Lending: An Empirical Investigation. Electronic Commerce Research and Applications, 11(5), 495-503.

Laurell, C. Sandström, C., and Suseno, Y., 2019. Assessing the interplay between crowdfunding and sustainability in social media. Technological Forecasting \& Social Change, 141, 117-127.

Lehner, O. M., 2013. Crowdfunding social ventures: a model and research agenda. Venture Capital, 15(4), 289-311.

Löher, J., 2017. The interaction of equity crowdfunding platforms and ventures: an analysis of the preselection process. Venture Capital, An International Journal of Entrepreneurial Finance, 19(1-2), 51-74.

Lu, C. T., Xie, S., Kong, X. and Yu, P. S., 2014. Inferring the impacts of social media on crowdfunding. In Proceedings of the 7 th ACM international conference on Web search and data mining (pp. 573-582).

Mezei, J., 2018. Credit risk evaluation in peer-to-peer lending with linguistic data transformation and supervised learning. Proceedings of the 51st Hawaii International Conference on System Sciences. URI: http://hdl. handle.net/10125/50056 ISBN: 978-0-9981331-1-9, pp. 1366-1375.

Mollick, E. R., 2014. The dynamics of crowdfunding: An exploratory study. Journal of Business Venturing, 29, 1-16.

Mollick, E. R. and Kuppuswamy, V., 2014. After the Campaign: Outcomes of Crowdfunding. UNC Kenan-Flagler Research Paper No. 2376997. Available at SSRN: https://ssrn.com/abstract=2376997.

Moritz A. and Block, J.H., 2016. Crowdfunding: A Literature Review and Research Directions. In: Brüntje D., Gajda O. (eds) Crowdfunding in Europe. FGF Studies in Small Business and Entrepreneurship. Springer, Cham.

O'Brien, R. M., 2007. A caution regarding rules of thumb for variance inflation factors. Quality \& Quantity, 41, 673-690.

Paschen, J., 2017. Choose wisely: Crowdfunding through the stages of the startup life cycle. Business Horizons, 60, 179-188.

Park, O.-C. and Hopkins, R., 1993. Instructional conditions for using dynamic visual displays: a review. Instructional Science, 21, 427-449.

Ryan, R.M. and Deci, E.L., 2000. Intrinsic and extrinsic motivations: classic definitions and new directions. Contemporary Educational Psychology, 25(1), 54-67.

Ryu, S. and Kim, Y. G., 2016. A Typology of Crowdfunding Sponsors: Birds of a Feather Flock Together? Electronic Commerce Research and Applications, 16, 43-54.

Sahaym, A., Datta, A., and Brooks, B., 2019. Crowdfunding success through social media: Going beyond entrepreneurial orientation in the context of small and medium-sized enterprises. Journal of Business Research, https://doi.org/10.1016/j.jbusres.2019.09.026.

Shahab, Y., Ye, Z., Riaz, Y. and Ntim, C. G., 2019. Individual's financial investment decision-making in reward-based crowdfunding: evidence from China. Applied Economics Letters, 26(4), 261-266.
Senecal, S. and Nantel, J., 2004. The influence of online product recommendations on consumers' online choices. Journal of Retailing, 80,159-169.

Shen, D., Krumme, C. and Lippman, A., 2010. Follow the Profit or the Herd? Exploring Social Effects in Peer-to-Peer Lending. 2nd International Conference on Social Computing, Minneapolis, 20-22 August 2010, 137-144.

Summers, J.; Chidambaram, L. \& Young, A., 2016. Venture Signals and Social Media Buzz in Crowdfunding: Are "Buzzworthy" Projects Worth the Hype? 49th Hawaii International Conference on System Sciences (HICSS), Koloa, HI, 2016, pp. 3515-3524, doi: 10.1109/HICSS.2016.440.

Thies, F., Wessel, M. and Benlian, A., 2014. Understanding the Dynamic Interplay of Social Buzz and Contribution Behavior within and between Online Platforms: Evidence from Crowdfunding. Completed Research Paper. Proceedings of the Thirty Fifth International Conference on Information Systems, Auckland.

Trusov, M., Bucklin, R. E. and Pauwels, K., 2009. Effects of word-ofmouth versus traditional marketing: findings from an Internet social networking site. Journal of Marketing, 73(5), 90-102.

Wang, X. and Tu, Y., 2016. The Existence of Herding in P2P Lending and the Rationality of It - An Empirical Study from China. Journal of Economics, Business and Management, 4(11), 652-659.

Xia, L. and Bechwati, N. N., 2008. Word of mouse: the role of cognitive personalisation in online consumer reviews. Journal of Interactive Advertising, 9(1), 3-13.

Xiaofen, J. and Yiling, Z., 2009. The impacts of online word-of-mouth on consumer's buing intention on apparel: an empirical study. Proceedings of the 2009 International Symposium on Web Information Systems and Applications (WISA' 09), May 22-24, Nanchang, P. R. China.

Xu, A., Yang, X., Rao, H., Fu, W. T., Huang, S. W. and Bailey, B. P., 2014. Show me the money! An analysis of project updates during crowdfunding campaigns. In Proceedings of the $32^{\text {nd }}$ annual ACM conference on human factors in computing systems (pp. 591-600). ACM. Canada. https://doi.org/10.1145/2556288.2557045

Young, T., 2013. Everything guide to crowdfunding. Avon. Adams Media. Yu, S., Johnson, S., Lai, C., Cricelli, A., and Fleming, L., 2017. Crowdfunding and regional entrepreneurial investment: An application of the CrowdBerkeley database. Research Policy, 46, 1723-1737.

Zhang, J. and Chen, W., 2019. Crowdfunding technological innovations: interactions between consumer benefits and rewards. Technovation, 84, 11-20.

Zhang, J. and Liu, P., 2012. Rational Herding in Microloan Markets. Management Science, 58(5), 892-912.

Zheng H, Li, D., Wu J. and Yun, X., 2014. The role of multidimensional social capital in crowdfunding: a comparative study in China and US. Information \& Management, 51(4), 488-496. 